\title{
RESEARCH
}

Open Access

\section{Follow-up evaluation of the immunological status of children admitted for acute cerebral nervous system infections: a retrospective study}

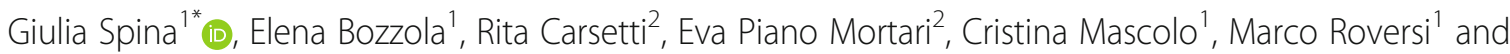
Alberto Villani ${ }^{1}$

\begin{abstract}
Background: Acute Cerebral Nervous System Infections (ACNS) may cause death or severe complications even to promptly treated children. The role of the immune system in influencing the course and the outcome of meningitis has been studied but it is not yet completely understood. The aim of the research is to ascertain whether children who experienced ACNS infection had a normal immune system.

Methods: Patients under 18 years of age admitted at Bambino Gesù Children from January 2006 till June 2016 for meningitis were asked to participate to the follow-up study. The immune status was evaluated both clinically and by laboratory investigations.

Results: Most of the patients over 3 years at follow up had at least one immunological alteration at follow-up evaluation (74\%). Considering ACNS infection etiology, certain pathogens were almost exclusive of patients affected by some immunological alteration, regardless of their age.

Discussion: Our preliminary results indicate that sub-clinical immunological defects may be associated to ACNS pediatric infections. Moreover, to the best of our knowledges, this is the first study correlating pathogens to immune evaluation in ACNS infections. It is, however, important to underline the high frequency of persistent immunological alterations in the analyzed patients. Further studies are needed to confirm our conclusions.

Conclusions: We recommend an immunological assessment at follow up evaluation in children who experienced an ACNS infection.
\end{abstract}

Keywords: Acute cerebral nervous system infections, Children, Immune system

\footnotetext{
* Correspondence: giulia.spina@opbg.net

'University/Hospital Department of Pediatrics, Pediatric and Infectious

Diseases Unit, Bambino Gesù Children's Hospital, IRCCS, Rome, Italy

Full list of author information is available at the end of the article
}

(c) The Author(s). 2021, corrected publication 2021. Open Access This article is licensed under a Creative Commons Attribution 4.0 International License, which permits use, sharing, adaptation, distribution and reproduction in any medium or format, as long as you give appropriate credit to the original author(s) and the source, provide a link to the Creative Commons licence, and indicate if changes were made. The images or other third party material in this article are included in the article's Creative Commons licence, unless indicated otherwise in a credit line to the material. If material is not included in the article's Creative Commons licence and your intended use is not permitted by statutory regulation or exceeds the permitted use, you will need to obtain permission directly from the copyright holder. To view a copy of this licence, visit http://creativecommons.org/ licenses/by/4.0/. The Creative Commons Public Domain Dedication waiver (http://creativecommons.org/publicdomain/zero/1. 0/) applies to the data made available in this article, unless otherwise stated in a credit line to the data. 


\section{Introduction}

Acute cerebral nervous system (ACNS) infection are a spectrum of diseases that include cerebellitis, meningitis, encephalitis, and meningoencephalitis.

Bacterial meningitis is a devastating and lifethreatening disease, in developing as well as in developed countries. Despite recent advances in antimicrobial therapy and vaccine development, bacterial meningitis still poses a significant cause of morbidity and mortality in populations at risk, such as in infants, children, and the elderly or immunocompromised patients [1, 2]. Although meningitis remains a relatively rare entity in most congenital or acquired immunodeficiencies, the onset of bacterial meningitis and sepsis may be the first and exclusive sign of an underlying immunodeficiency, particularly when other bacteria than Neisseria meningitidis (NM) are isolated [3, 4].

The role of the immune system in determining the course and outcome of meningitis is not well understood. Humoral immunodeficiency has been reported in patients with invasive diseases caused by Streptococcus Pneumoniae (SP), Haemophilus Influenzae (HI) or by other capsulated pathogens [5]. Agammaglobulinemia should also be suspected in a patient with community-acquired bacterial meningitis [4]. Interestingly, Native Americans, Native Alaskans, and African Americans that experience higher rates of invasive bacterial infections due to $\mathrm{HI}$ and SP, also show an increased prevalence of congenital immunodeficiencies (such as the Common Variable or Severe Combined Immuno-Deficiency). It is not yet clear whether Toll-Like Receptors 2, 4, and 9 polymorphisms may predict both susceptibility and unfavourable course of bacterial meningitis caused by SP or NM [6-10]. It has, however been demonstrated that TLR- triggered cytokine secretion is involved in the pathogenesis of meningococcal disease [11]. Finally, deficiency of opsonization and phagocytosis, with or without a preserved splenic function, increase the risk of meningitis. Individuals with deficiency of a single complement protein have a greatly increased risk of both carrying the putative pathogen in the nasal mucosa and developing the disease [12]. Altogether, these findings suggest that immune dysregulation and immunodeficiency may predispose to bacterial meningitis.

Few studies conducted on a pediatric population evaluated the risk of developing bacterial meningitis in the presence of any underlying immunodeficiencies.

Aim of the study is to ascertain whether children who experienced ACNS Infections had a normal immune system.

\section{Materials and methods}

\section{Human subjects}

We enrolled patients admitted to the Bambino Gesù Children Hospital, Roma, Italy, between 1st January
2006 and 30th June 2016 with the following diagnosis of ACNS infection: meningitis, meningoencephalitis, encephalitis and cerebellitis. We included all patients younger than 18 years. Exclusion criteria for selection were varicella-zoster virus infection and any of the following comorbidities: neurological disorders, chronic diseases, malignancy, known acquired or congenital immunodeficiency and/or immunosuppressive therapy. All patients underwent at least one follow-up evaluation to check clinical, vaccination and immunological status. To avoid bias due to possible effects of the recent disease, immunological exams were performed at least 1 month after the acute phase. At the follow-up evaluation, all patients were in good clinical condition, without either fever or other acute symptoms.

\section{Laboratory tests}

In details, laboratory tests included measurement of: serum antibodies against vaccine antigens; serum levels of Immunoglobulin (Ig) M, G, and A; complement levels; lymphocyte subpopulations; proliferation and differentiation of B cells. Serum antibodies against vaccine antigens, namely tetanus, HI, SP, Bordetella pertussis and Hepatitis $B$ virus and serum levels of IgM, IgA and IgG were measured using a commercial ELISA kit for each antigen (Binding Site) and an in-house ELISA respectively. Coating of plates was carried out with an anti-IgM/IgG/IgA (Cat \#109-006-064). Peroxidaseconjugated anti-IgM (cat \#109-36-129), anti-IgG (cat \#109-036-008), or anti-IgA (cat \#109-036-011) (all from Jackson Immunoresearch) were used as primary antibodies. Purified serum IgG and IgA, and IgM purified from a myeloma cell line (Jackson Immunoresearch) were used as standards. Peripheral blood mononuclear cells (PBMCs) were isolated from blood on density gradient centrifugation (Lympholyte, CEDARLANE). PBMCs were loaded with CFSE (Life Technologies) to track divided cells. Briefly, $1 \times 10^{6}$ cells $/ \mathrm{mL}$ were resuspended in PBS 1\% FCS and loaded with $1 \mu \mathrm{M}$ CFSE for $20 \mathrm{~min}$ at $37^{\circ} \mathrm{C}$. Cells were then stimulated with $0.25 \mu \mathrm{M}$ CpG-B ODN2006 (Hycult Biotech). Flow cytometry was then conducted to count the lymphocyte subpopulations and to evaluate proliferation and differentiation of $\mathrm{B}$ cells (CD3, CD4, CD8, CD19, CD24, CD38, IgM, CD16/ 56). Cells were stained with the appropriate combination of fluorochrome-conjugated antibodies, according to standard techniques. Dead cells were excluded from analysis by side/forward scatter gating. At least 50,000 events gated on living cells were analysed, whenever possible, for each sample. Samples were acquired on a BD Fortessa X-20.

The following four criteria were considered diagnostic for immunological alteration: absence of antibodies against vaccine antigens; age-related reduction of 
immunoglobulin values; reduction of B cell populations, namely memory $\mathrm{B}$ cells; defective proliferation and differentiation of B cells.

\section{Statistics}

$\mathrm{R}$, version 3.2.3 (R Foundation for Statistical Computing, Vienna, Austria. http://www.R-project.org/) was used for data analysis. We compared the laboratory results of our patients with age-matched normal values $[13,14]$. The ttest was used for comparison of means of Ig and lymphocyte subclass counts. A $p$ value less than 0.05 was considered significant.

\section{Results}

In the study period, 127 participants were identified. Of those, we excluded 30 patients because of a concomitant VZV infection. Our final sample included 97 patients affected by ACNS infections. As the efficiency of the immune system varies according to the different age groups, we evaluated the aetiologies and immunological status of ACNS infections in two subpopulations: patients younger than 3 years old (group A) and patients older than 3 years old (group B) at the follow-up evaluation. The demographic and clinical characteristics of our sample are listed in Table 1.

Table 1 Characteristics of patients with ACNS infections

\begin{tabular}{|c|c|c|c|}
\hline \multirow{2}{*}{$\begin{array}{l}\text { Group A } \\
\text { Patients (n) } 35\end{array}$} & & \multicolumn{2}{|l|}{ Group B } \\
\hline & & \multicolumn{2}{|l|}{ Patients (n) 62} \\
\hline Gender & & Gender & \\
\hline Male & $21(60 \%)$ & Male & $38(61.3 \%)$ \\
\hline Female & $14(40 \%)$ & Female & $24(38.7 \%)$ \\
\hline \multicolumn{2}{|l|}{ Age at diagnosis (years) } & \multicolumn{2}{|l|}{ Age at diagnosis (years) } \\
\hline Range & $0.01-2.43$ & Range & $0.06-17.68$ \\
\hline Mean & $0.42(S D 0.62)$ & Mean & 4.07 (SD 4.38) \\
\hline \multicolumn{2}{|l|}{ Age at follow-up (years) } & \multicolumn{2}{|l|}{ Age at follow-up (years) } \\
\hline Range & $0.01-2.43$ & Range & $3.15-19.46$ \\
\hline Mean & 1.47 (SD 0.81) & Mean & 9.82 (SD 4.59) \\
\hline \multicolumn{2}{|c|}{ Length of hospitalization (days) } & \multicolumn{2}{|c|}{ Length of hospitalization (days) } \\
\hline Range & $6-492$ & Range & $5-153$ \\
\hline Mean & 39.26 (SD 83.65) & Mean & 30.21 (SD 24.33) \\
\hline \multicolumn{2}{|l|}{ Type of ACNS infection } & \multicolumn{2}{|l|}{ Type of ACNS infection } \\
\hline Meningitis & $22(62.9 \%)$ & Meningitis & $38(62.9 \%)$ \\
\hline Meningoencephalitis & $7(20 \%)$ & Meningoencephalitis & $15(24.2 \%)$ \\
\hline Encephalitis & $5(14.3 \%)$ & Encephalitis & $3(4.8 \%)$ \\
\hline Cerebellitis & $1(2.8 \%)$ & Cerebellitis & $5(8.1 \%)$ \\
\hline \multicolumn{2}{|l|}{ Pathogens (n,\%) } & \multicolumn{2}{|l|}{ Pathogens (n,\%) } \\
\hline $\mathrm{SP}$ & $2(5.7 \%)$ & $\mathrm{SP}$ & $16(25.8 \%)$ \\
\hline SA & $4(11.4 \%)$ & SA & $3(4.8 \%)$ \\
\hline NM & $4(11.4 \%)$ & NM & $16(25.8 \%)$ \\
\hline $\mathrm{HI}$ & $3(8.6 \%)$ & $\mathrm{HI}$ & $4(6.4 \%)$ \\
\hline EC & $1(2.8 \%)$ & E. Coli & $1(1.6 \%)$ \\
\hline EV & $11(31.4 \%)$ & Enterovirus & $6(9.7 \%)$ \\
\hline HHV6 & $5(14.3 \%)$ & HHV6 & $3(4.8 \%)$ \\
\hline EBV & $2(5.7 \%)$ & EBV & $4(6.4 \%)$ \\
\hline HSV1 & $1(2.8 \%)$ & HSV1 & $1(1.6 \%)$ \\
\hline $\mathrm{TBC}$ & $2(5.7 \%)$ & $\mathrm{TBC}$ & $6(9.7 \%)$ \\
\hline $\mathrm{KP}$ & $0(0 \%)$ & K. Pneumoniae & $1(1.6 \%)$ \\
\hline
\end{tabular}

Legend: Group A patients younger than 3 years at follow-up (FUP), Group B patients older than 3 years at FUP, SP Streptococco Pneumoniae SA Streptococco Agalactiae, NM Neisseria Meningitidis, HI Haemophilus Influenzae, EC Escherichia Coli, EV Enterovirus, HHV6 Human Herpes Virus 6, EBV Epstein Bar virus, HSV1 Herpes virus type 1, TBC Mycobacterium Tuberculosis, KP Klebsiellae Pneumoniae 
Table 2 Immunoglobulin levels in patients affected by ACNS infection at the follow-up evaluation and comparison with reference values

\begin{tabular}{|c|c|c|c|c|c|c|c|c|c|c|c|c|}
\hline \multirow[t]{2}{*}{ Age } & \multicolumn{3}{|c|}{$3-5$ years } & \multicolumn{3}{|c|}{$6-8$ years } & \multicolumn{3}{|c|}{ 9-11 years } & \multicolumn{3}{|c|}{$12-17$ years } \\
\hline & & Ref & $P$-value & & Ref & $P$-value & & Ref & $P$-value & & Ref & $P$-value \\
\hline \multicolumn{13}{|l|}{$\lg \mathrm{A}(\mathrm{mg} / \mathrm{dL})$} \\
\hline average & 119,45 & 98 & NS & 118,5 & 113 & NS & 155,36 & 127 & NS & 146,38 & 136 & NS \\
\hline SD & 49,94 & & & 42,58 & & & 50,76 & 14,08 & & 75,16 & 16,40 & \\
\hline \multicolumn{13}{|l|}{$\operatorname{lgG}(\mathrm{mg} / \mathrm{dL})$} \\
\hline Average & 833,18 & 1117 & $P<0.01$ & 939,37 & 1164 & $P<0.05$ & 1134,64 & 1164 & NS & 955,71 & 1105 & $P<0.05$ \\
\hline SD & 146,42 & & & 258,93 & & & 260,37 & 72,21 & & 258,54 & 56,42 & \\
\hline \multicolumn{13}{|l|}{$\operatorname{lgM}(\mathrm{mg} / \mathrm{dL})$} \\
\hline Average & 122 & 119 & NS & 106,13 & 121 & NS & 137,27 & 129 & NS & 147,43 & 132 & NS \\
\hline SD & 55,4 & & & 41,01 & & & 55,61 & & & 146,65 & & \\
\hline
\end{tabular}

The majority of our patients had a primary involvement of the meninges, either in the form of meningitis or meningoencephalitis. A similar distribution of the types of infection was found in the two subgroups. The most frequent pathogens isolated in all groups were: NM, SP, Enterovirus (EV), Herpes Human Virus 6 (HHV6) and Mycobacterium Tuberculosis (TBC). The relative frequency of the pathogens for each group is shown in Table 1.

Immunoglobulin levels and lymphocytes subpopulations averages were compared with age-related reference values as showed in Tables 2 and 3. At least one immunological alteration as defined by the given criteria was detected in most of our sample, considering patients older than 3 years at the follow-up evaluation
(74\%). Moreover, $51.4 \%$ of the eligible population had some alterations in the B cell proliferation test, while 16 patients had at least one B cell phenotype change (23\%). The IgG values were significantly lower than the standard in patients with more than 3 years of age $(p<0.05)$. We did not consider such differences to be significant in patients under 3 years as immunoglobulin levels at this age are greatly variable. As for the lymphocytes subpopulations, CD3 and CD4 counts proved to be significantly lower than the reference values in 11- to 17-years patients $(p<0.001)$; moreover, we found a significantly lower than the reference CD16/56 count in patients of 6 to 10 and 11 to 17 years of age ( $p<0.01$ and $p<0.00001$ respectively). Routine vaccinations had been administered to most of our population. Nonetheless, we

Table 3 Lymphocytes sub-populations values in patients with ACNS infection older than 3 years of age compared with reference values

\begin{tabular}{|c|c|c|c|c|c|c|c|c|c|}
\hline \multirow[t]{2}{*}{ Age } & \multirow[t]{2}{*}{$3-5$ years } & \multirow[b]{2}{*}{ Ref } & \multirow[b]{2}{*}{$P$-value } & \multirow[t]{2}{*}{$6-10$ years } & \multirow[b]{2}{*}{ Ref } & \multirow[b]{2}{*}{$P$-value } & \multirow[t]{2}{*}{$11-17$ years } & \multirow[b]{2}{*}{ Ref } & \multirow[b]{2}{*}{$P$-value } \\
\hline & & & & & & & & & \\
\hline \multicolumn{10}{|l|}{ CD3 (\%) } \\
\hline medium & 67,74 & 66 & NS & 68,4 & 69 & NS & 69,55 & 73 & $P<0.001$ \\
\hline SD & 4,77 & & & 5,51 & & & 4,29 & & \\
\hline \multicolumn{10}{|l|}{ CD4 (\%) } \\
\hline medium & 37,71 & 38 & NS & 36,85 & 37 & NS & 36,83 & 41 & $P<0.05$ \\
\hline SD & 5,85 & & & 5,7 & & & 6,25 & & \\
\hline \multicolumn{10}{|l|}{ CD8 (\%) } \\
\hline medium & 22,7 & 23 & NS & 24,74 & 25 & NS & 25,91 & 26 & NS \\
\hline SD & 4,44 & & & 5,42 & & & 6,76 & & \\
\hline \multicolumn{10}{|l|}{ CD19 (\%) } \\
\hline medium & 20,46 & 21 & NS & 16,3 & 18 & NS & 14,71 & 14 & NS \\
\hline SD & 6,11 & & & 6,25 & & & 4,05 & & \\
\hline \multicolumn{10}{|l|}{ CD16/56 (\%) } \\
\hline medium & 10,66 & 9 & NS & 13,88 & 9 & $P<0.01$ & 14,13 & 9 & $P<0.00001$ \\
\hline SD & 4,18 & & & 7,35 & & & 4,06 & & \\
\hline
\end{tabular}


noticed the reduction below the protective values against tetanus, SP, HI and pertussis in 13, 28, 18 and 54\% of all cases respectively. Complement levels $(\mathrm{C} 3, \mathrm{C} 4)$ and $\mathrm{CH} 50$ levels were evaluated in 50 and 20 patients respectively with no statistically significant abnormality revealed.

Considering the etiology of the ACNS infections, we observed that certain pathogens were almost exclusive of patients affected by some immunological alteration, regardless of their age group. Epstein-Barr Virus (EBV) and HHV6 were isolated only in patients with at least one immunological alteration $(p<0.001)$. NM has been mostly detected in patients older than 3 years without any immunological alteration. Moreover, 9 different pathogens were observed in patients younger than 3 years old with at least one immunological alteration as showed by Fig. 1 . On the other hand, only 5 pathogens were isolated in patients older than 3 years without any immunological changes. The association of a given immunological alteration with the related pathogens are shown in Fig. 1.

\section{Discussion}

In our case series, we found a statistically significant difference in the CD3, CD4 and CD16/56 counts, compared to age-related reference values [14]. In detail, most of the altered values were found in the oldest patients, aged $11-17$ years $(p<0.05)$, suggesting that immunity plays an important role in protecting adolescents from ACNS infection. Few studies have highlighted Tlymphocyte alterations in patients with meningitis. In particular, a study conducted on 19 patients documented CD3, CD4 and CD16/56 lower level without any significant differences [15], congruous with other findings [16, 17].

Otherwise, most of the patients had normal complement levels. In literature as well, complements deficiencies are rarely linked to ACNS infections. Complement levels may increase or decrease in ACNS infections depending on the balance between complement production and consumption in each phase of the disease [18].

Immunoglobulin deficiencies are more associated to ACNS infections than primary complement deficiencies [19-21]. Usually, a combined IgG and IgA deficiency or IgG deficiency and neutrophil chemotaxis abnormality have been documented [16] In our study, all patients had normal IgA values while IgM and IgG levels were lower than the age-related standard. More specifically, IgG levels were significantly lower than the reference in most of our sample at the follow-up evaluation $(p<0.05)$.

Considering qualitative immunological tests, we observed that $51.4 \%$ of the eligible population had some Blymphocyte proliferation abnormalities. Other reports have studied functional B cell alterations documenting low levels of B cell proliferations in patients with meningococceal meningitis [22].

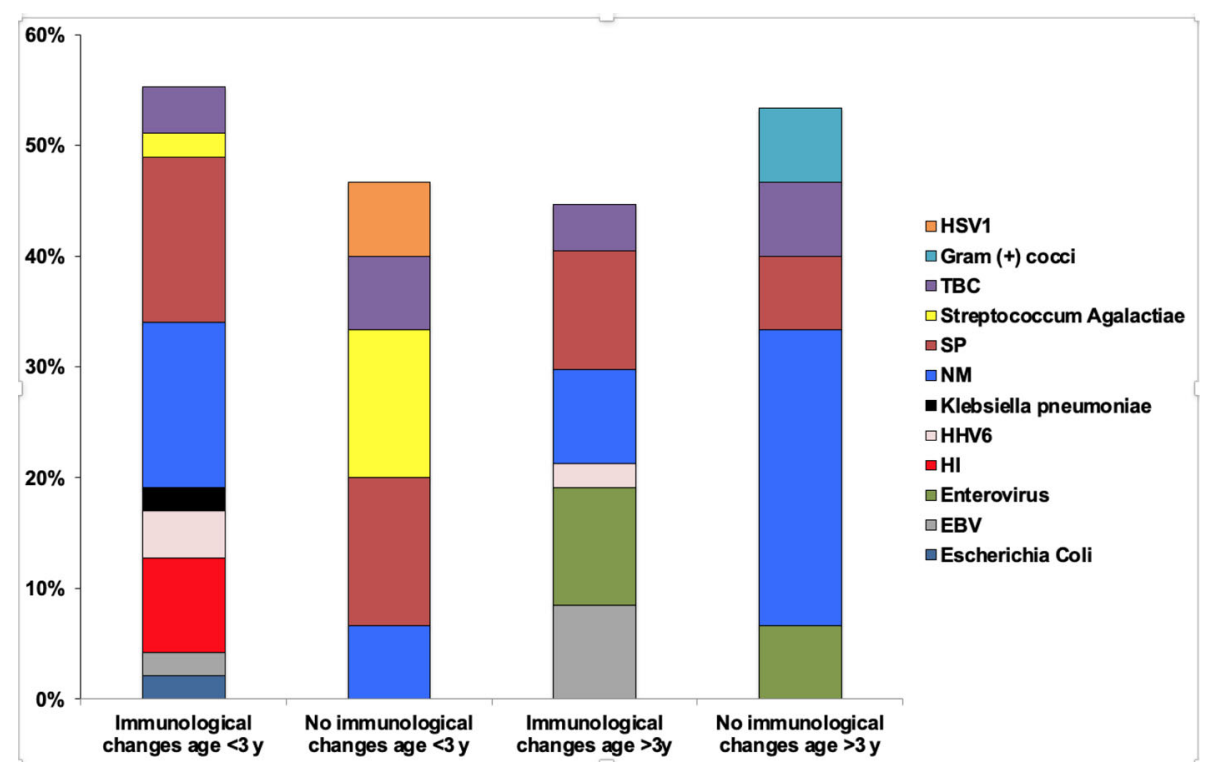

Legend: HSV1: herpes virus type 1; TBC: Mycobacterium tuberculosis; SP: Streptococcum Pneumoniae; NM: Neisseria Meningitidis; HHV6: Herpes Human Virus 6; HI: Haemophilus Influenzae;

Fig. $1 \mathrm{Imm}$ unological evaluation and pathogens detected in patients younger than 3 years at follow-up evaluation (Group A) and in patients older than 3 years at follow-up evaluation (Group B). HSV1: herpes virus type 1; TBC: Mycobacterium tuberculosis; SP: Streptococcum Pneumoniae; NM: Neisseria Meningitidis; HHV6: Herpes Human Virus 6; HI: Haemophilus Influenzae 
To our knowledge, this is the first study correlating the causative pathogens to immune evaluation in ACNS infections. In particular, in our experience, Escherichia Coli, Klebsiella Pneumoniae and HI were more often isolated in patients younger than 3 years at diagnosis, who had at least one immunological alteration. Moreover, a broader variety of pathogens has been documented in patients with immunological abnormalities at all ages. Typical pathogens, such as NM and SP, were mostly observed in patients without any immune alteration.

Our study has some limitations. As in all retrospective studies, we could not consider the risk of developing the disease in subjects with a given immunodeficiency. Also, we did not have a control group, as we used the normal value reported in literature as a control. Moreover, despite evaluating patients at least 1 month after the admission, while in good clinical conditions, we could not exclude that the immune system dysregulation was a direct consequence of the ACNS infection rather than its cause. Finally, our study was based on a relatively small sample size, owing to the rarity of the disease.

Further studies are necessary to confirm our results as to evaluate the causal relationship between immunological status and clinical sequelae in patients with ACNS infections.

\section{Conclusion}

We suggest that an immunological evaluation should be performed in pediatric patients with ACNS infections. In fact, our preliminary results indicate that ACNS infections occur in children who have subclinical, but measurable immunological alterations.

More specifically, we suggest a quantitative assessment of B cells, IgA, IgM and IgG in patients with a previous bacterial meningitis, at least 1 month after the onset of the disease or later, to avoid bias due to possible effects of the recent disease. Moreover, complement evaluation should also be considered in patients who experienced NM infection or recurrent infections.

Finally, atypical pathogens should be searched in patients with a suspected immunological alteration.

\section{Abbreviations}

ACNS: Acute Cerebral Nervous System Infections (ACNS); NM: Neisseria meningitidis; SP: Streptococcus Pneumoniae; HI: Haemophilus Influenzae; Ig: Immunoglobulin; EBV: Epstein-Barr Virus; EV: Enterovirus; HHV6: Herpes Human Virus 6; TBC: Mycobacterium Tubercoulosis

\section{Acknowledgements}

Not applicable.

\section{Authors' contributions}

GS coordinated the study; GS designed the study; EB analyzed clinical data; RC and EPM analyzed immunological data. The author(s) read and approved the final manuscript.

\section{Funding}

This research did not receive any specific grant from funding agencies in the public, commercial, or not-for-profit sectors.

\section{Availability of data and materials}

At Bambino Gesù Children Hospital.

Ethics approval and consent to participate

Not applicable.

\section{Consent for publication}

Collected before patient enrollment; availability of data at Bambino Gesù Children Hospital.

\section{Competing interests}

No competing interests.

\section{Author details}

${ }^{1}$ University/Hospital Department of Pediatrics, Pediatric and Infectious Diseases Unit, Bambino Gesù Children's Hospital, IRCCS, Rome, Italy. ${ }^{2} \mathrm{~B}$ cell Physiopathology Unit, Immunology Research Area, Bambino Gesù Children Hospital, Rome, Italy.

Received: 24 July 2020 Accepted: 21 January 2021

Published online: 02 February 2021

\section{References}

1. Heckenberg SG, Brouwer MC, van de Beek D. Bacterial meningitis. Handb Clin Neurol. 2014;121:1361-75.

2. Adriani KS, Brouwer MC, Geldhoff M, Baas F, Zwinderman AH, Morgan BP, Harris $\mathrm{CL}$, et al. Common polymorphisms in the complement system and susceptibility to bacterial meningitis. J Infect. 2013;66:255e262.

3. Hoffman $\mathrm{O}$, Weber JR. Pathophysiology and treatment of bacterial meningitis. Ther Adv Neurol Disord. 2009;2(6):401-12.

4. Overturf GD. Indications for the Immunological Evaluation of Patients with Meningitis. Clin Infect Dis. 2003;36(2):189-94.

5. Martinot M, Oswald L, Parisi E, Etienne E, Argy N, Grawey I, De Briel D, et al. Immunoglobulin deficiency in patients with Streptococcus pneumoniae or Haemophilus influenzae invasive infections. Int J Infect Dis. 2014;19:79-84.

6. Mogensen TH, Paludan SR, Kilian M, Ostergaard L. Live Streptococcus pneumoniae, Haemophilus influenzae, and Neisseria meningitidis activate the inflammatory response through Toll-like receptors 2, 4, and 9 in speciesspecific patterns. J Leukoc Biol. 2006;80(2):267-77.

7. Wright V, Hibberd M, Levin M. Genetic polymorphisms in host response to meningococcal infection: the role of susceptibility and severity genes. Vaccine. 2009;27(Suppl 2):B90-102.

8. Brouwer MC, Read RC, van de Beek D. Host genetics and outcome in meningococcal disease: a systematic review and meta-analysis. Lancet Infect Dis. 2010;10(4):262-74.

9. Gowin E, Świątek-Kościelna B, Kałużna E, Nowak J, Michalak M, Wysocki J, Januszkiewicz-Lewandowska D. Analysis of TLR2, TLR4, and TLR9 single nucleotide polymorphisms in children with bacterial meningitis and their healthy family members. Int J Infect Dis. 2017;60:23-8.

10. Tenhu E, Teräsjärvi J, Cruzeiro ML, Savonius O, Rugemalira E, Roine I, He O Pelkonen T. Gene Polymorphisms of TLR4 and TLR9 and Haemophilus influenzae Meningitis in Angolan Children. Genes (Basel). 2020;11(9):E1099.

11. Kvalsvig AJ, Unsworth DJ. The immunopathogenesis of meningococcal disease. J Clin Pathol. 2003:56:417-22.

12. Lewis LA, Ram S. Meningococcal disease and the complement system. Virulence. 2014;5(1):98-126.

13. Ugazio A, et al. Il bambino immunodepresso: Ed CEA; 1995:20-45

14. Sherearer WT, Rosenblatt HM, Gelman RS, Oyomopito R, Plaeger S, Stiehm ER, Wara DW, et al. Lymphocyte subsets in healty children from birth through 18 years of age. J Allergy Clin Immunol. 2003;112:973-80

15. Ahmadinejad Z, Bagherian H, Atarord L, Soodbakhsh A, Saheli G. Lymphocyte subsets, immunoglobulin levels, complement activity $\mathrm{CH} 50$, and phagocytic peroxide production in 19 Iranian patients with first episode of bacterial meningitis. J Microbiol Immunol Infect. 2011;44:83e87.

16. Lorraine J, Beard LJ, Thong YH. Immunological competence of children with pyogenic meningitis. Eur J Pediatr. 1981;136:231e5. 
17. Hassieb NM, Massoud MM, Amani IS. Study of cell mediated and humoral immunity in acute bacterial meningitis. J Egypt Public Health Assoc. 1990; 65:643e55.

18. Hildebrand J, Gowing E, Graziano FM. Identifying patients with immunodeficiencies: part 1. J Respir Dis. 2001;22:471e80.

19. Oordt-Speets AM, Bolijn R, van Hoorn RC, Bhavsar A, Kyaw MH. Global etiology of bacterial meningitis: A systematic review and meta-analysis. PLoS One. 2018;13(6):e0198772.

20. Kira R, Ihara K, Takada H, Gondo K, Hara T. Nonsense mutation in exon 4 of human complement $\mathrm{C9}$ gene is the major cause of Japanese complement C9 deficiency. Hum Genet. 1998;102:605e10.

21. Litzman J, Freiberger T, Brtohkova D. Early manifestations of C2 complement deficiency in the form of pyogenic infection in infancy. Paediatr Child Health. 2003;39:274e7.

22. Foster RA, Carling J, McKendrick MW, Lees A, Borrow R, Read RC, et al. Evidence of a Functional B-Cell Immunodeficiency in Adults Who Experience Serogroup C Meningococcal Disease. Clin Vaccine Immunol. 2009;16(5):692-8.

\section{Publisher's Note}

Springer Nature remains neutral with regard to jurisdictional claims in published maps and institutional affiliations.

Ready to submit your research? Choose BMC and benefit from:

- fast, convenient online submission

- thorough peer review by experienced researchers in your field

- rapid publication on acceptance

- support for research data, including large and complex data types

- gold Open Access which fosters wider collaboration and increased citations

- maximum visibility for your research: over $100 \mathrm{M}$ website views per year

At BMC, research is always in progress.

Learn more biomedcentral.com/submissions 